DOI 10.15517/rbt.v69i1.38916

\title{
Actuotaphonomic model of the mollusk fauna of Laguna de Mandinga, Veracruz, Mexico
}

\section{F. Raúl Gío-Argaez ${ }^{1 *}$, Catalina Gómez-Espinosa ${ }^{2} \&$ Saraí Romero $^{3}$}

1. Universidad Nacional Autónoma de México, Instituto de Ciencias del Mar y Limnología, Ciudad de México, México; raulgio@cmarl.unam.mx

2. Universidad Autónoma de Guerrero, Escuela Superior de Ciencias de la Tierra, Taxco el Viejo, Guerrero, México; c_gomez@ciencias.unam.mx

3. Universidad Veracruzana, Posgrado de la Facultad de Ciencias Biológicas y Agropecuarias, Tuxpan de Rodríguez Cano, Veracruz, México; iamsara@ciencias.unam.mx

*Correspondence

Received 03-VI-2020. Corrected 12-XI-2020. Accepted 18-XI-2020.

\begin{abstract}
Introduction: The taphonomic attributes of a faunal assemblage provide information about which agents affect the distribution and preservation of ancient or newly formed biogenic materials during depositional and post-depositional processes. Actuotaphonomy thus is a valuable tool for reconstructing fossil communities because it establishes analogies between observable processes in the present and those that happened in the past. Objective: The taphonomic attributes of a marginal marine environment were analyzed to assess the origin of fragmentation, bioerosion, and encrustation processes and the role of these characteristics in the deterioration of current sediment accumulations of mollusks (gastropods and bivalves). Methods: The material studied was collected from a shell-remain accumulation called "El Conchal" in the Laguna de Mandinga, Veracruz, a lagoonal complex located in the Gulf of México. Taphonomic analysis included fragmentation, bioerosion, and encrustation features on recent gastropods and bivalve's shells. The categories of each attribute were classified in three degrees: poor, regular and good. The analysis was performed only in complete shells. Results: A bulk sample of $1697.9 \mathrm{~g}$ was processed, recovering 1165 complete specimens, of which 5 genera of bivalves and 4 genera of gastropods were identified. The fragmentation and bioerosion were classified as regular (grade 1), this may be the results of the water energy in the environment, that permits a constant rework, and exhumation of the remains at the lagoon's water-sediment interface; meanwhile, three eroders were identified to ichnogenus level: Entobia, Oichnus, and Caulostrepsis, being Caulostrepsis the least abundant. The encrustation was classified as poor (grade 2); the result can be interpreted based on the ecosystem intrinsic conditions that do not allow many encrusting organisms to develop properly. The encrusters are represented by calcareous organisms including bryozoans, serpulids tubes, and barnacles. The results yielded an actuotaphonomic model that could be applicable to analogous ecosystems in Laguna de Mandinga (Mandinga Lagoon), in Veracruz, Mexico. Conclusions: In marine marginal environments as in lagoon areas the encrustation does not have an important role in the preservation or destruction of shelly assemblages, being taphonomically more important than fragmentation and bioerosion as potentially destructive agents that can be a source of loss of fidelity in the fossil record.
\end{abstract}

Key words: actuotaphonomic model; fragmentation; bioerosion; encrustation; lagoon; mollusk.

Gío-Argaez, F.R., Gómez-Espinosa, C., \& Romero, S. (2021).Actuotaphonomic model of the mollusk fauna of Laguna de Mandinga, Veracruz, Mexico. Revista de Biología Tropical, 69(1), 207-217. DOI 10.15517/rbt.v69i1.38916

The taphonomic attributes of a faunal assemblage provide information about which agents affect both the distribution and preservation of ancient or newly formed biogenic materials during their depositional and postdepositional processes. These processes are regulated by the surrounding environmental conditions and the life habits of the organisms 
that constitute such assemblages (Callender et al., 2002; El-Sorogy, 2015; Gómez-Espinosa, Gío-Argáez, Farinati, Aliotta, \& Salgado-Souto, 2018). Thus, actuotaphonomy is a valuable tool for reconstructing fossil communities because it establishes analogies between observable processes in the present and those that happened in the past. Actuotaphonomy helps elucidate the events that lead to preservation of organic remains, which in turn assists in interpretation of sedimentological and ecological conditions that gave rise to the formation of a fossil deposit (Gómez-Espinosa \& GíoArgáez, 2009).

Kowalewski, Flessa, and Hallman (1995) proposed a triple classification graphical approach to taphonomic interpretations, using a diagram called "ternary taphograms," in which a taphonomic signature is assigned to a specific degree of alteration. With this classification assigned according to the percentage of shell coverage, it can be "good" (extensive or abundant coverage), "medium" (moderate coverage), or "poor" (little or no coverage).

Mollusks are major components of many current and fossilized marine ecosystems, and thus have been frequently incorporated into taphonomic analyses, with a special focus on gastropods and bivalves (Gómez-Espinosa et al., 2018). The in situ study of preserved mollusk assemblages is essential for understanding the taphonomic processes involved in the preservation or destruction of shell remains before their burial (Erthal, Korsian, \& Simoes, 2013). For this reason, actuotaphonomic studies are particularly useful for predicting and estimating the physiochemical and/or biological processes that prevailed in a given environment, as well as speculating about the capability preserving mollusk assemblages in each environment (Kowalewski \& Labarbera, 2004).

Different characteristic conditions may lead to taphonomic losses that affect the preservation of remains in a taphonomically active zone (TAZ), where the greatest dissolution, destruction, or taphonomic alteration of shells occurs. Among these conditions are the permanence of the organisms on the surface, the energy of the system, currents, salinity, and anthropogenic activity (Parsons-Hubbard et al., 1999; Olszewski, 2004; Gordillo, Bayer, Boretto, \& Charó, 2014).

The objective of the present study was to analyze the different degrees of taphonomic alteration that might enhance either the preservation or destruction of a gastropod and bivalve assemblage in the present marine marginal depositional environment of the Laguna de Mandinga, Veracruz, Mexico. By characterizing the fragmentation, bioerosion, and encrustation on both gastropod and bivalve shells, along with the subsequent construction of ternary taphograms for each of these taphonomic attributes, we generated an actuotaphonomic model that may be applicable in analogous ecosystems.

\section{MATERIALS AND METHODS}

Study site: Laguna de Mandinga is located in the state of Veracruz, Mexico $\left(19^{\circ} 00^{\prime} 00^{\prime \prime}\right.$ $19^{\circ} 06^{\prime} 00^{\prime \prime} \mathrm{N} \& 96^{\circ} 02^{\prime} 00^{\prime}$ ' $\left.96^{\circ} 06^{\prime} 00^{\prime \prime} \mathrm{W}\right), 18$ $\mathrm{km}$ South of Veracruz Port (Fig. 1). One of the main coastal lagoons along the Gulf of Mexico (Krutak, 1971; Reguero \& García-Cubas, 1994), Laguna de Mandinga is a sedimentary environment of the Quaternary made of a fluvial accumulation of fine to very fine particle size, consisting of sand, silt, and clay overlying sandy and alluvial sediments. In some areas, it emerges with the gravel derived from the accumulation of mainly molluscan shells (Contreras, 1985). The fact that Laguna de Mandinga generates high concentrations of organic remains makes it a suitable location for taphonomic studies. The samples for this study were collected in a shell-remain accumulation called "El Conchal" located in "Laguna Redonda".

At present, Mandinga is recognized as a tourist location with the development of commercial fishing. This status has meant that the lagoon and the channels that connect it to the Jamapa River have been regularly dredged since 1980 (Heimo, Siemens, \& Hebda, 2004).

Sediment sampling and processing: A total of $1697.9 \mathrm{~g}$ of sediment was collected 

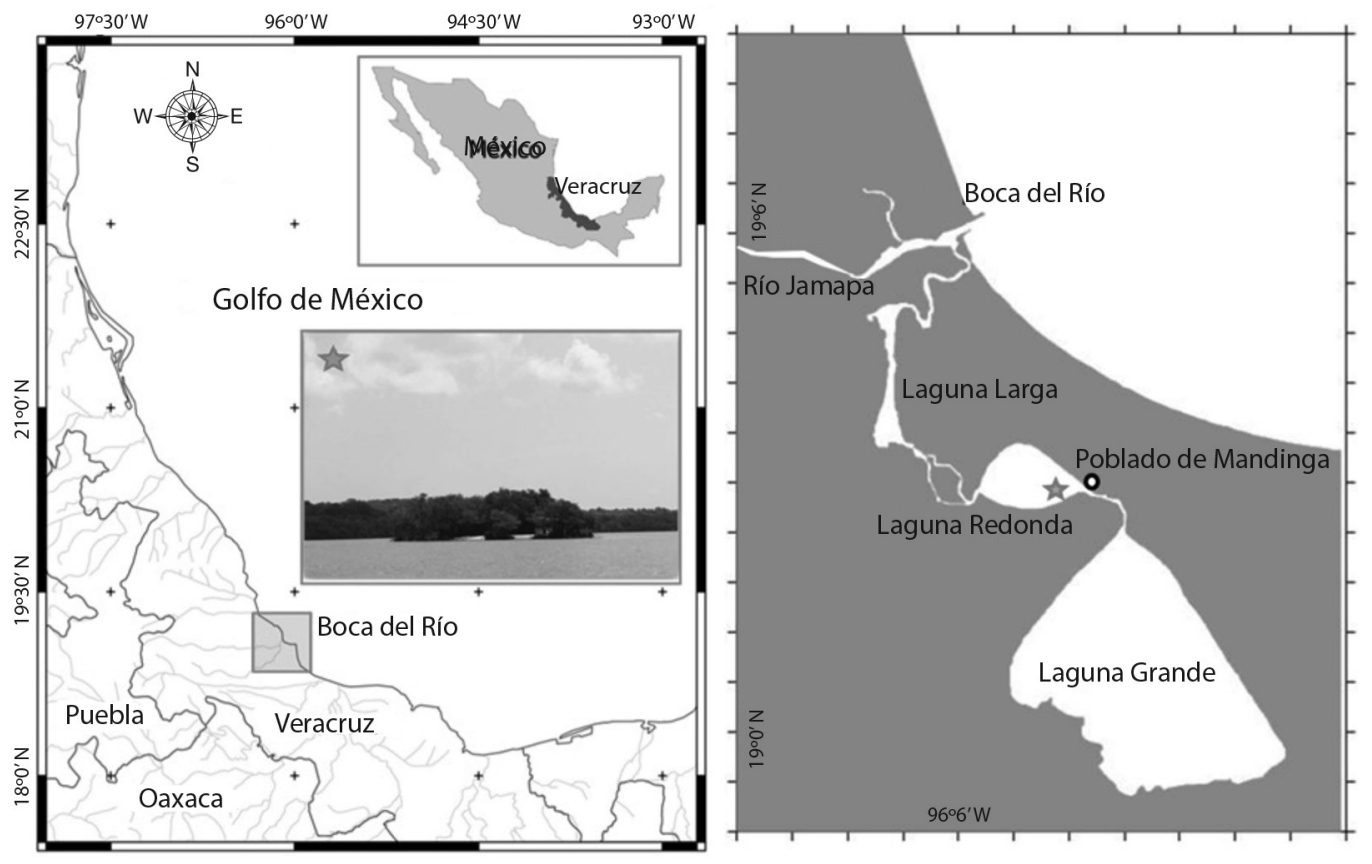

Fig. 1. Location of the study area "Laguna de Mandinga" Veracruz, close up mark with a star "El Conchal" shell remain accumulation.

from the ends and core from a shell mound known locally as "El Conchal", following the sieving method described by Anderson, McBride, Taylor, and Byrnes (1998). The sample was processed in the Laboratory of Environmental Micropaleontology, ICMyL, UNAM. Only complete specimens were included in the present taphonomic analysis, defined as retention of more than $70 \%$ of the original shell or valve surface. Among those with a smaller preservation percentage, we retained gastropod specimens that still had a last whorl and/or columella and bivalves that still had a hinge. A total of 1165 specimens were evaluated, of which 173 were gastropods and 922 were bivalves.

Taxonomic identification, taphonomic attributes, and ternary taphograms: All bivalves and gastropods sampled, along with bioeroding and encrusting organisms associated with them, were taxonomically identified according to the illustrated catalogs of GarcíaCubas and Reguero $(2004,2007)$ for bivalve mollusks and gastropods from the Gulf of Mexico and the Caribbean Sea. The identification of ichnogenus and encrusting was carried out following the ethological classification of Seilacher (1964) and the World Register of Marine Species platform (http://www. marinespecies.org/). The compared taphonomic attributes considered were fragmentation, bioerosion, and encrustation, assessed using ternary diagrams based on Kowalewski, Flessa and Hallman (1995).

\section{RESULTS}

Taxonomic identification: From the analyzed sample ( $\mathrm{N}=1165)$, we identified five genera of bivalves $(\mathrm{N}=922)$ : Anadara Gray, 1847; Crassostrea Sacco, 1897; Ischadium Jukes-Browne, 1905; Mulinia Gray, 1837, and Rangia Desmoulins, 1832. We also identified four gastropod genera ( $\mathrm{N}=173)$ : Bailya Smith, 1944; Cerithideopsis Thiele, 1929; Nassarius Duméril, 1805; and Neritina Lamarck, 1816 (Fig. 2). Among the bioeroding organisms 


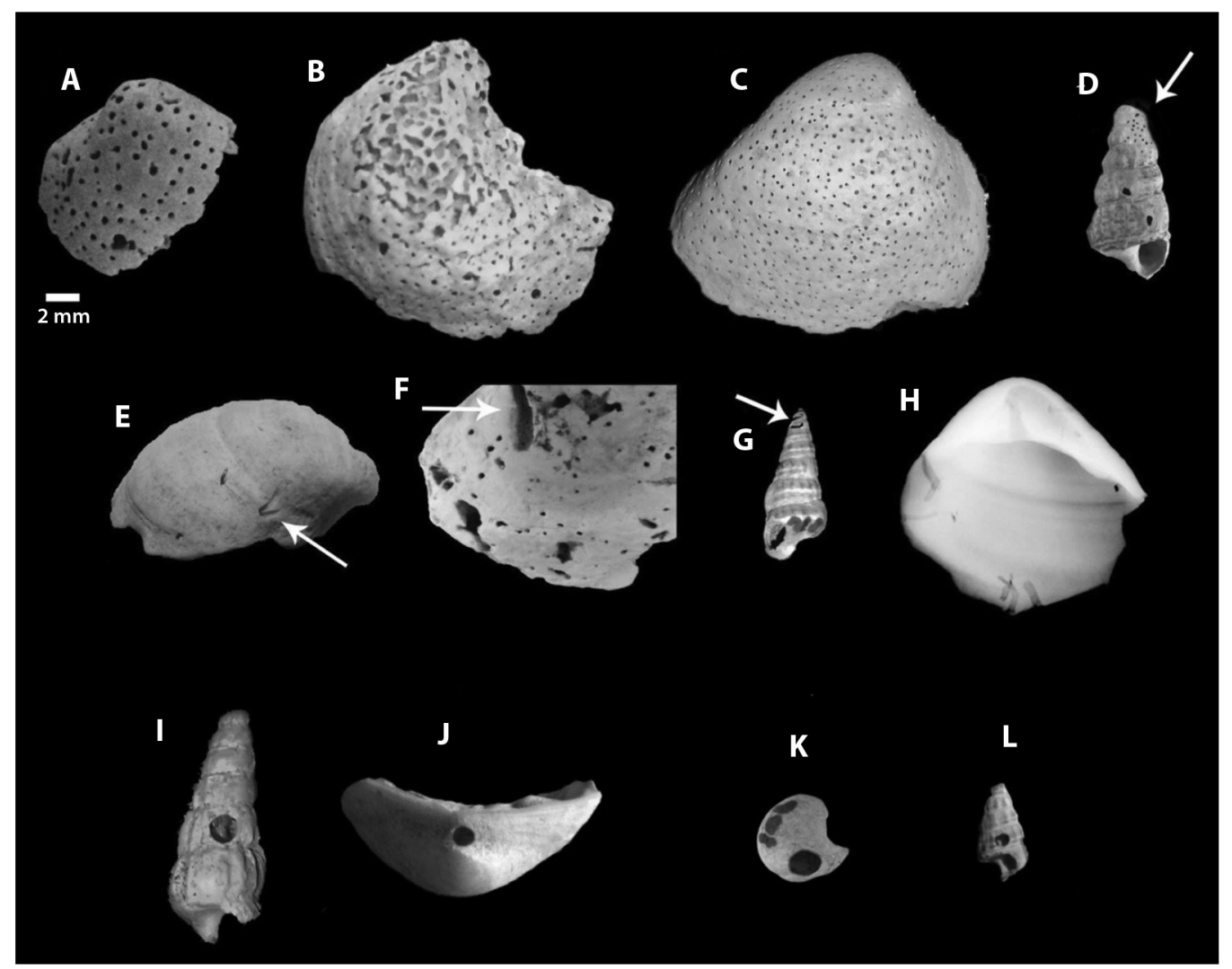

Fig. 2. Identification of bioerosive traces. A-D. Entobia perforations. E-F. Caulostrepsis perforations,

I-L. Oichnus perforations.

found in the sample, three types of perforations were identified related respectively to ichnogenus Entobia Bronn, 1937; Caulostrepsis Clarke, 1908; and Oichnus Bromley, 1981. The specimens presented either one or more types of perforations per individual.

Ethological classification:

Domichnia Seilacher, 1964

Ichnogenus Entobia Bronn, 1837

Type ichnospecies Entobia cretacea Portlock, 1843

Description: Most of the perforations were small, rounded, and widely distributed (Fig. 2A, Fig. 2B, Fig. 2C, Fig. 2D). Some perforations were so strongly marked that they caused shells to lose their shape because of fragmentation. Perforation was more commonly found in bivalves than in gastropods, possibly because of the greater surface area of bivalves.

Ichnogenus Caulostrepsis Clarke, 1908

Type ichnospecies Caulostrepsis taeniola

\section{Clarke, 1908}

Description: This ichnogenus was the least common in the sample. It was observed only in the outer layers of bivalves, exhibiting a wider diameter at the beginning of the perforation than at the end. C. taeniola was found in the gastropod shell towards the apex, manifesting as shallow elongated perforations (Fig. 2E, Fig. 2F, Fig. 2G, Fig. 2H).

Ethological classification:

Praedichnia Seilacher, 1964

Ichnogenus Oichnus Bromley, 1981 
Type ichnospecies Oichnus simplex

Bromley, 1981

Description: This perforation was the second most abundant type in the sample, appearing in both bivalves and gastropods, although more commonly in bivalves. Perforations were frequently located at the umbo of bivalves and at the last whorl of gastropods but were seen towards the apical region of some specimens (Fig. 2I, Fig. 2J, Fig. 2K, Fig. 2L).

Regarding the encrusting specimens detected, we identified calcareous serpulid polychaete tubes and calcareous bryozoan and barnacle skeletons. The polychaete tubes were the most common of the three. Serpulid polychaetes were found in both the dorsal and ventral surfaces of the bivalve shells analyzed (Fig. 3A, Fig. 3B, Fig. 3C, Fig. 3D), as well as the external surface of gastropods (Fig. 3C).

Bryozoans from the Order Cheilostomatida Nusk, 1852 were identified in four bivalves in the sample, either on the ventral surface of the valves or on top of other encrusting serpulids and barnacles (Fig. 3D, Fig. 3E, Fig. 3G). Barnacles of the genus Amphibalanus Pitombo, 2004 were recognized on the ventral surface of two bivalve specimens, at the umbo region of this location, and it is inferred that encrustation happened postmortem (Fig. 3F, Fig. 3G).

Taphonomic attributes and ternary taphograms: Table 1 represents the taphonomic attribute percentage according to the coverage degree of the shells, based on the number of specimens observed in each sample.

Fragmentation was observed in $58.1 \%$ of the total sample; bivalves were the most affected group. While bioerosion appears in a great number (47\%) of mollusk specimens analyzed and encrustation is quite scarce (5\%) in the sample.

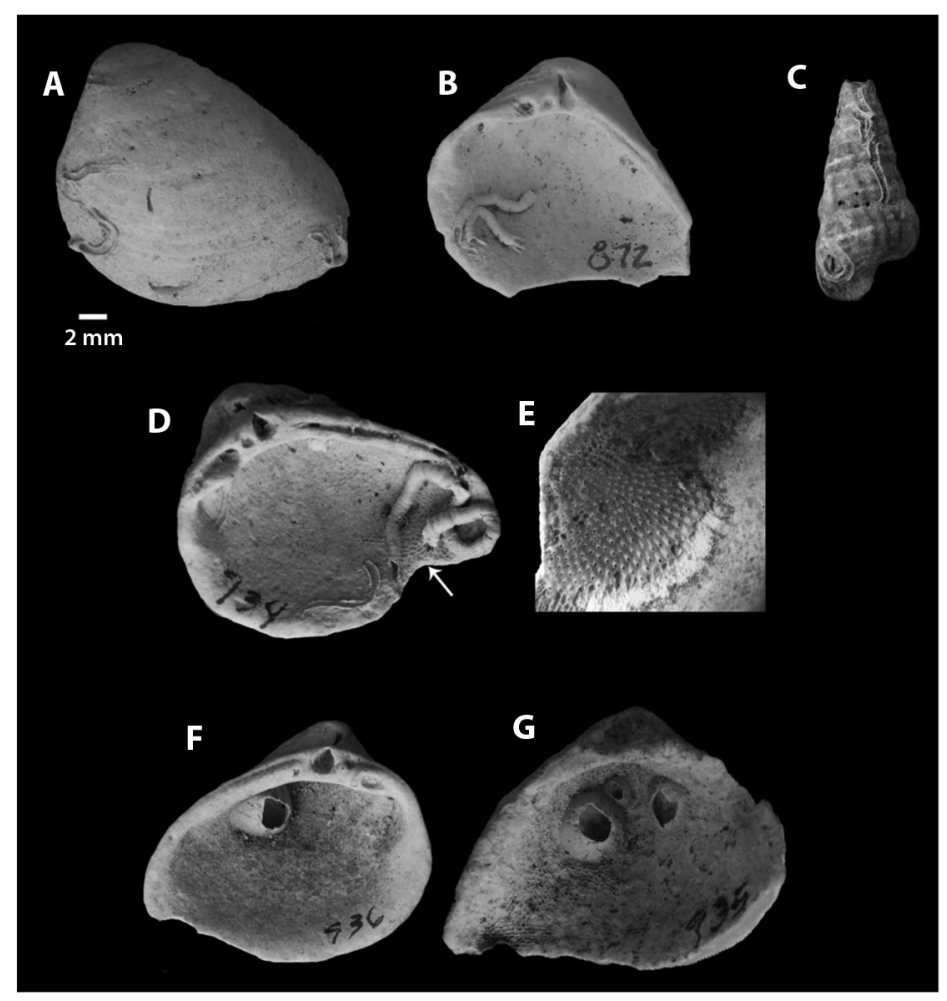

Fig. 3. Presence of encrusting organisms on mollusk shells. A-D. Serpulid polychaetes. D-E, G. Bryozoan colony. F-G. Barnacles. 
TABLE 1

Total number of specimens and taphonomic attributes analyzed (fragmentation, bioerosion, and encrustation)

\begin{tabular}{lcccccc} 
& \multicolumn{3}{c}{ Bivalves $(\mathrm{N}=992)$} & \multicolumn{3}{c}{ Gastropods $(\mathrm{N}=173)$} \\
Taphonomic attribute & Poor (Grade 2) & Regular (Grade 1) & Good (Grade 0) & Poor (Grade 2) & Regular (Grade 1) & Good (Grade 0) \\
Fragmentation & $416(41.9 \%)$ & $489(49.3 \%)$ & $87(8.8 \%)$ & $100(57.8 \%)$ & $57(32.9 \%)$ & $16(9.3 \%)$ \\
Bioerosion & $526(53 \%)$ & $440(44.3 \%)$ & $26(2.7 \%)$ & $90(52 \%)$ & $65(37.6 \%)$ & $18(10.4 \%)$ \\
Encrustation & $942(9 \%)$ & $48(4.8 \%)$ & $2(0.20 \%)$ & $172(99.4 \%)$ & $1(0.06 \%)$ & - \\
\hline
\end{tabular}

TABLE 2

Organisms exhibiting bioerosion and encrustation according to their taphonomic degree and taxonomic group

\begin{tabular}{|c|c|c|c|c|c|c|}
\hline & \multicolumn{3}{|c|}{ Bivalves } & \multicolumn{3}{|c|}{ Gastropods } \\
\hline & Poor & Regular & Good & Poor & Regular & Good \\
\hline \multicolumn{7}{|l|}{ Bioeroders } \\
\hline Entobia & & 181 & 17 & & 28 & 12 \\
\hline Caulostrepsis & & 83 & & & 7 & \\
\hline Oichnus & & 109 & 1 & & 18 & \\
\hline Entobia/Caulostrepsis & & 29 & 5 & & & 2 \\
\hline Entobia/Oichnus & & 35 & 3 & & 1 & \\
\hline Caulostrepsis/Oichnus & & 2 & & & 11 & 4 \\
\hline Entobia/Caulostrepsis/Oichnus & & 1 & & & & \\
\hline \multicolumn{7}{|l|}{ Encrusters } \\
\hline Barnacles & & 1 & & & & \\
\hline Bryozoans & & 3 & & & & \\
\hline Serpulids & & 43 & 1 & & 1 & \\
\hline Barnacles/Bryozoans & & & 1 & & & \\
\hline Serpulids/Bryozoans & & 1 & & & & \\
\hline
\end{tabular}

Poor $($ Grade 2$)=$ absent attribute; regular $($ Grade 1$)=<50 \%$ coverage of the shell; good $($ Grade 0$)=>50 \%$ coverage of the shell.

Analysis of the results of ternary taphograms (Fig. 4) for bivalves showed mediumgrade $(<50 \%$ shell coverage) fragmentation and bioerosion (Fig. 4A, Fig. 4B), according to Kowalewski, Flessa and Hallman (1995). The gastropod fragmentation also was medium grade (Fig. 4A), but the bioerosion was poor (Fig. 4B). For both groups, encrustation (Fig. 4C) was poor (absent attribute).

Among bivalves, fragmentation was present in $58.1 \%$, bioerosion in $47 \%$, and encrustation in $5 \%$. Within the gastropods, fragmentation was present in $42.2 \%$, bioerosion in $48 \%$, and encrustation in $0.6 \%$. Of the total, fragmentation was present in $55.7 \%$, bioerosion in $47.1 \%$, and encrustation in $4.4 \%$.
Based on the taphonomic analysis, bivalves were the most affected group (Table 2).

\section{DISCUSSION}

Modern marine environments offer information about past geological processes and conditions that affected organisms and their eventual burial. However, the fossil record in brackish water bodies, such as coastal lagoons, has a lower diversity of representation compared to the marine record because of how organisms are preserved and the ephemeral nature of the habitats (Adomat, Gishler \& Oschmann, 2015). For this reason, actuotaphonomic studies in brackish water bodies are 


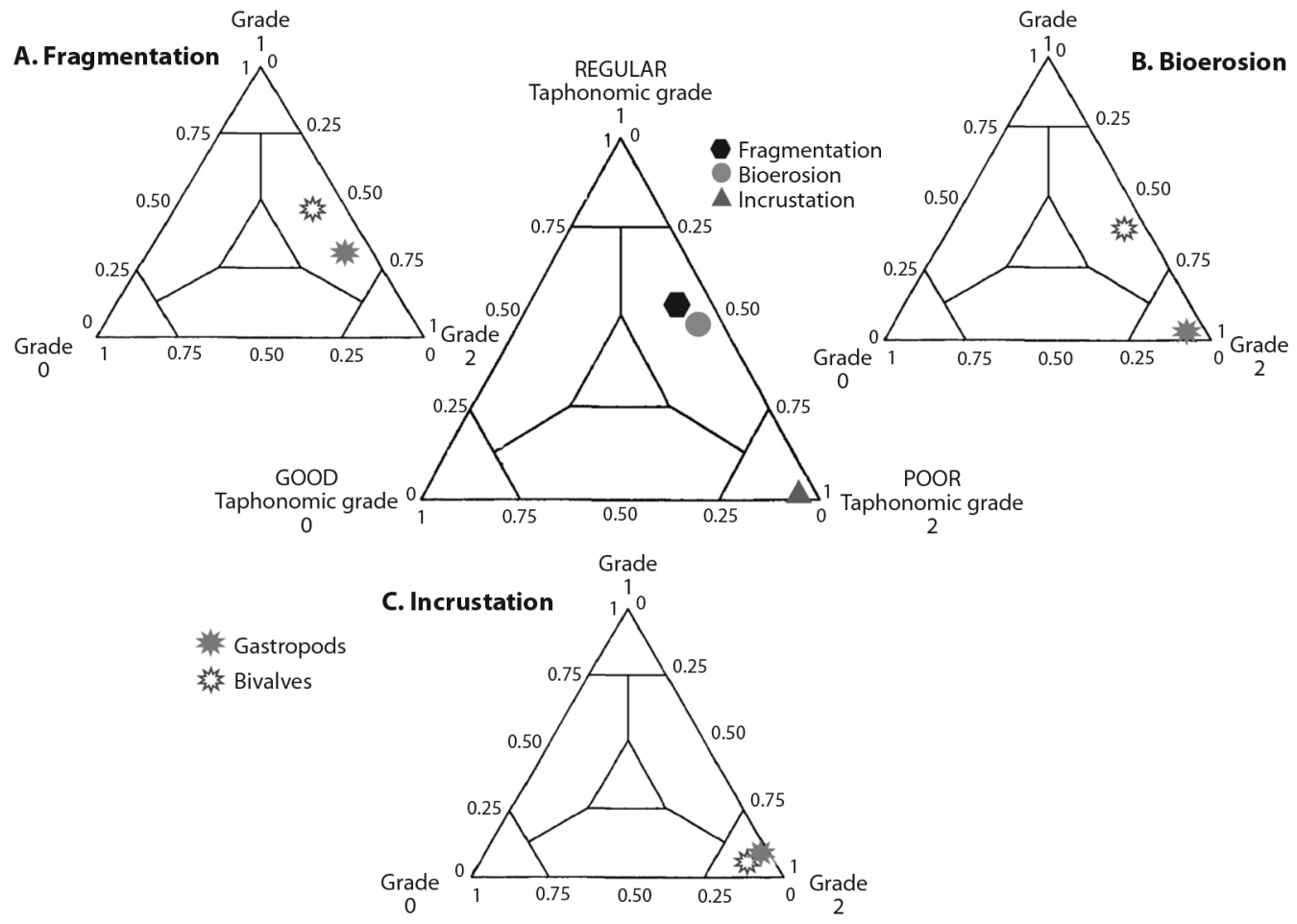

Fig. 4. Ternary taphograms. Global representation of the taphonomic attributes analyzed. Fragmentation and bioerosion exhibit a regular degree, while encrusting presents a poor degree. A. Bivalve and gastropod fragmentation, regular. B. Bivalve bioerosion, regular; gastropod bioerosion, poor. C. Bivalve and gastropod encrustation, poor.

relevant to understanding the past extrinsic and intrinsic conditions of these ecosystems.

Different factors regulate the abundance and composition of fossil deposits, such as susceptibility to modification and destruction by organisms, taphonomic conditions exposed in the environment, and the time scale accumulation (Behrensmeyer \& Kidwell, 1985). These factors are clearly observable in current marine-marginal environments, where ecological interpretations of the species can be made based on the factors that influence the transport of the organic remains.

In order to study a recent mollusk assemblage in a marine marginal environment, just as the ones that are developed in coastal lagoons, requires consideration of the energy rates, environmental interactions, and trophic relationships of the system under study.
These factors regulate molluscan communities and are crucial tools in interpreting their taphonomic attributes.

Taphonomic interpretation: The sample position in each ternary taphogram expresses the variation of taphonomic characteristics, which may result from the different conservation environments (hydrodynamic regime, biological activity, degree of subaerial exposure), variation in size, and architecture of the shells (Kowalewski, Flessa, \& Hallman 1995). The use of taphograms saves space and allows a quick comparison of the taphonomic characteristics among samples.

Fragmentation was observed in $58.1 \%$ of the total sample, and bivalves were the most affected group. This characteristic is associated not only with high environmental energy but 
also with biological interactions. The origin of the fragments could depend on different stages of taphonomic processes (depredation, bioturbation, and biostratinomic processes), system energy, and anthropogenic action (opening of canals) that provokes constant cycles of rework and exhumation of organic remains (Kidwell, Fürsich, \& Aigner, 1986; Zuschin, Stachowitsch, \& Stanton, 2003).

Because of the nature of the encrusting organisms and bioeroders, it is believed that they developed in underwater conditions, so that the shells were deposited and accumulated in islets called "conchales". Bioerosion was present in a great number (47\%) of mollusk specimens collected from Laguna de Mandinga, but encrustation (5\%) was quite scarce. Such scarcity might arise from the considerable sediment reworking and exhumation that characterize the study site. Both the burial and the frequent subaerial exposure may have protected the shells from bioeroders and encrusting organisms (Lescinsky, Edinger, \& Risk, 2002).

Most of the organisms responsible for the perforations identified in our sample were clionid sponges (Porifera), which produce the ichnogenus Entobia. To a lower degree, there were carnivorous gastropods that produce the ichnotrace Oichnus and the serpulid polychaetes that produce the ichnogenus Caulostrepsis. All three ichnogenera were present in both bivalves and gastropods, but their incidence was higher in bivalves. The same ichnofossils and their higher prevalence on bivalves were registered on recent shell assemblages from a siliciclastic beach on the Gulf of Mexico (Gómez-Espinosa et al., 2018).

Given the relatively high percentage of bioerosion detected in the Laguna de Mandinga sample $(47 \%)$, it can be inferred that a great number of the analyzed organisms spent considerable time in the TAZ, where bioeroding organisms could settle on the exposed surface of the mollusk shells (Davies, Powell, \& Stanton, 1989; Walker, Parson-Hubard, Powell, \& Brett, 1998).

Encrusting organisms were found in only 5 $\%$ of the specimens, and all but one individual were bivalves. Most encrustations were located on the ventral surface of the valves, suggesting a postmortem occupation, most likely to gain protection (McKinney, 1996). A large number of encrusting bryozoans were observed colonizing the surface of other encrusting organisms (i.e., serpulid polychaetes and barnacles), so that the first arrivals could be considered as secondary colonizers capable of inhabiting surfaces with varying degrees of roughness and/or curvature (Gherardi \& Bosence, 1999; Gibson, 1992; Taylor \& Wilson, 2003). The encrusting bryozoans did not have a preference regarding substrate specificity, and differences were related to the variable physical stability of the shells exhibiting different frequencies of circumrotatory growth (Jackson, 1984; McKinney, 1996).

The high rate of fragmentation and low degree of biogenic processes calculated for Laguna de Mandinga imply that the taphonomic processes occurring in mollusk assemblages are primarily driven by a high sedimentation rate and a constant reworking of the skeletal concentrations in the area. These conclusions agree with inferences from the models of fossil concentrations by Kidwell (1986) and Kidwell, Fürsich, and Aigner (1986).

In some cases, the bioerosion and encrustation contributed to the deterioration of the remains, producing the subsequent fragmentation of the shells. These effects would be expected to inhibit the conservation of the shells and could be the cause of their loss from the fossil record.

Several factors may be responsible for the low fouling density of mollusks. Among these are a relatively short exposure period before the burial (Brett et al., 2011); low nutrient levels (Lescinsky et al., 2002), constant movement of the rests or rapid wear of scales, and decreases in biological activity because of high turbidity (Parsons-Hubbard, 2005).

Formation of skeletal concentrations: In the fossil record, evidence of disturbance prior to burial can be used to infer peculiarities of the burial history or the life habits of the organisms (Brett \& Baird, 1986). This association 
can be inferred in the present work thanks to the taphonomic analysis, in which cause-effect relationships of processes observed in Mandinga Lagoon could be established and contrasted with observations in the obtained sample.

Kidwell et al. (1986) recognized three types of processes responsible for skeletal concentration formations: sedimentological, biogenic and diagenetic. In Laguna de Mandinga, the taphonomic processes in mollusks are determined by a high rate of sedimentation and a constant reworking of skeletal concentrations. These conditions produce a high rate of fragmentation and a low degree of biogenic processes.

The formation of different biotopes (islets) in the lagoon traces to the constant dragging of sediments and dead organisms, which after a certain time are associated with a death assemblage (thanatocoenosis) with high sedimentation rates. Thus, as a result of constant reworking and high sedimentation rates, the encrusting organisms would rarely fossilize because of the long periods of time they require to become established on the remains (Asch \& Collie, 2008).

Death assemblage represents the first step in the formation of a fossil assemblage, so our results represent a useful tool for biological and paleontological studies aimed at understanding the ecological, geological, and taphonomic processes that occur in marine-marginal environments with similar characteristics.

Ethical statement: authors declare that they all agree with this publication and made significant contributions; that there is no conflict of interest of any kind; and that we followed all pertinent ethical and legal procedures and requirements. All financial sources are fully and clearly stated in the acknowledgements section. A signed document has been filed in the journal archives.

\section{ACKNOWLEDGMENTS}

We thank Miriam Moranchel, Bachelor in Earth Sciences, for her contributions and review of texts in English. At the same time, we thank the biologist Brenda Martínez Villa for her support in this project.

\section{RESUMEN}

Modelo actuotafonómico de la fauna de moluscos de Laguna de Mandinga, Veracruz, México. Introducción: Los atributos tafonómicos de los conchales proveen información acerca de cuáles agentes afectan la distribución y preservación de la acumulación de materiales biogénicos recientes o fósiles, especialmente durante las etapas deposiconales y postdeposicionales. La actuotafonomía es una herramienta valiosa para la reconstrucción de las comunidades fósiles, para establecer analogías entre los procesos observables en el presente con los que ocurrieron en el pasado. Objetivos: Evaluar el impacto de los rasgos tafonómicos y su papel en la formación de los conchales en ambientes de lagunas costeras Métodos: El material estudiado fue recolectado en una acumulación de restos de conchas llamado "El Conchal" en la Laguna de Mandinga, Veracruz, un complejo lagunar ubicado en el Golfo de México. El análisis tafonómico incluye las características tafonómicas de fragmentación, bioerosión e incrustación en conchas de gasterópodos y bivalvos recientes. Las categorías de cada atributo se clasificaron en tres grados: pobre, medio y alto. El análisis fue realizado solo en conchas completas. Resultados: Se procesaron $1697.9 \mathrm{~g}$ de sedimentos, recuperando 1165 ejemplares completos, de los cuales se identificaron 5 géneros de bivalvos y 4 géneros de gasterópodos. La fragmentación y bioerosión se clasificaron como un "grado regular", esto puede ser el resultado de la energía del agua en el ambiente, que permite el constante retrabajo y la exhumación de los restos en la interfase agua-sedimento en la laguna; en tanto que, se identificaron tres erosionadores a nivel de género, estos corresponden a los icnogéneros: Entobia, Oichnus y Caulostrepsis, siendo Caulostrepsis el menos abundante. La incrustación mostró un "grado pobre"; el resultado puede interpretarse basado en las condiciones intrínsecas del ecosistema que no permiten que muchos incrustantes se desarrollen de la manera adecuada. Los incrustantes están representados por organismos calcáreos incluyendo briozoarios, tubos de serpúlidos y balanos. Se analizaron los atributos tafonómicos para generar un modelo actuotafonómico que pueda ser aplicable a ecosistemas análogos en el registro fósil. Conclusiones: En ambientes marino marginales como son las áreas lagunares la incrustación no tiene un papel importante en la preservación o destrucción de los conchales, siendo tafonómicamente más importante la fragmentación y bioerosión como agentes potencialmente destructivos que pueden ser un recurso de pérdida de la fidelidad en el registro fósil.

Palabras clave: modelo actuotafonómico; fragmentación; bioerosión; incrustación; laguna; moluscos. 


\section{REFERENCES}

Adomat, F., Gischler, E., \& Oschmann, W. (2016). Taxonomic and taphonomic signatures of mollusk shell concentrations from coastal lagoon environments in Belize, Central America. Facies, 62(5). DOI: 10.1007/ s10347-015-0454-4

Anderson, L.C., McBride, R.A., Taylor, M.J., \& Byrnes, M.R. (1998). Late Holocene record of community replacement preserved in time-averaged molluscan assemblages, Louisiana chenier plain. Palaios, 13(5), 488-499.

Asch, R.G., \& Collie, J.S. (2008). Changes in a benthic megafaunal community due to disturbance from bottom fishing and the establishment of a fishery closure. Fishery Bulletin, 106(4), 438-456.

Behrensmeyer, A.K., \& Kidwell, S.M. (1985). Taphonomy's contributions to paleobiology. Paleobiology, 11(1), 105-119.

Brett, C.E., \& Baird, G.C. (1986). Comparative taphonomy: a key to paleoenvironmental interpretation based on fossil preservation. Palaios, 1(3), 207-227.

Brett, C.E., Parsons-Hubbard, K.M., Walker, S.E., Ferguson, C., Powell, E.N., Staff, G., ... \& Raymond, A. (2011). Gradients and patterns of sclerobionts on experimentally deployed bivalve shells: synopsis of bathymetric and temporal trends on a decadal time scale. Palaeogeography, Palaeoclimatology, Palaeoecology, 312(3-4), 278-304.

Callender, W.R., Staff, G.M., Parsons-Hubbard, K.M., Powell, E.N., Rowe, G.T., Walker, S.E., ... \& Heise, E.A. (2002). Taphonomic trends along a forereef slope: Lee Stocking Island, Bahamas. I. Location and water depth. Palaios, 17(1), 50-65.

Contreras, E.F. (1985). Las Lagunas Costeras de Tabasco: un Ecosistema en Peligro. Centro de Ecodesarrollo. Distrito Federal, México: Secretaría de Pesca.

Davies, D.J., Powell, E.N., \& Stanton Jr., R.J. (1989). Taphonomic signature as a function of environmental process: shells and shell beds in a hurricane-influenced inlet on the Texas Coast. Palaeogeography, Palaeoclimatology, Palaeoecology, 72, 317-356.

El-Sorogy, A.S. (2015). Taphonomic processes of some intertidal gastropod and bivalve shells from Northern Red Sea coast, Egypt. Pakistan Journal of Zoology, 47(5), 1287-1296

Erthal, F., Kotzian, C.B., \& Simoes, M.G. (2013). Multistep taphonomic alterations in fluvial mollusk shells: a case study in the Touro Passo Formation (Pleistocene-Holocene), Southern Brazil. Palaios, 30(5), 388-402.

García-Cubas, A. \& Reguero, M. (2004). Catálogo ilustrado de los moluscos gasterópodos del Golfo de México y Mar Caribe. México, D.F.: Universidad Nacional Autónoma de México.

García-Cubas, A. \& Reguero, M. (2007). Catálogo ilustrado de los moluscos bivalvos del Golfo de México y Mar Caribe. Distrito Federal, México: Universidad Nacional Autónoma de México.

Gherardi, D.F.M., \& Bosence, D.W.J. (1999). Modeling of the ecological succession of encrusting organisms in Recent coralline-algal frameworks from Atol das Rocas, Brazil. Palaios, 14(2), 145-158.

Gibson, M.A. (1992). Some epibiont-host and epibiont-epibiont relationships from the Birdsong Shale Member of the Lower Devonian Ross Formation (west-central Tennessee, USA). Historical Biology, 6(2), 113-132.

Gómez-Espinosa, C. \& Gío-Argáez, F.R. (2009). Tafonomía. Revista Ciencias, 96, 16-23.

Gómez-Espinosa, C., Gío-Argáez, F.R., Farinati, E.A., Aliotta, S., \& Salgado-Souto, S.A. (2018). Bioerosion and encrustation rates in recent mollusk death assemblages on a supratidal siliciclastic setting, Playa Norte, Veracruz State, Mexico. Arabian Journal of Geosciences, 11(8), 188.

Gordillo, S., Bayer, M.S., Boretto, G., \& Charó, M. (2014). Mollusk shells as bio-geo-archives: Evaluating environmental changes during the Quaternary. Argentina: Springer International Publishing.

Heimo, M., Siemens, A.H., \& Hebda, R. (2004). Prehispanic changes in wetland topography and their implications to past and future wetland agriculture at Laguna Mandinga, Veracruz, Mexico. Agriculture and Human Values, 21(4), 313-327.

Jackson, J.B.C. (1984). Ecology of cryptic coral reef communities. III. Abundance and aggregation of encrusting organisms with particular reference to cheilostome bryozoan. Journal of Experimental Marine Biology and Ecology, 75(1), 37-57.

Kidwell, S.M. (1986). Models for fossil concentrations: paleobiologic implications. Paleobiology, 12(1), 6-24.

Kidwell, S.M., Fürsich, F.T., \& Aigner, T. (1986). Conceptual Framework for the Analysis and Classification of Fossil Concentrations. Palaios, 1(3), 228-238.

Kowalewski, M., \& Labarbera, M. (2004). Actualistic Taphonomy: Death, Decay, and Disintegration in Contemporary Settings. Palaios, 19(5), 423-427.

Kowalewski, M., Flessa, K.W., \& Hallman, D.P. (1995). Ternary taphograms: triangular diagrams applied to taphonomic analysis. Palaios, 10(5), 478-483.

Krutak, P.R. (1971). The Recent Ostracoda of Laguna Mandinga, Veracruz, Mexico. Micropaleontology, 17(1), 1-30. 
Lescinsky, H.L., Edinger, E., \& Risk, M.J. (2002). Mollusc shell encrustation and bioerosion rates in a modern epeiric sea: taphonomy experiments in the Java Sea, Indonesia. Palaios, 17(2), 171-191.

McKinney, F.K. (1996). Encrusting organisms on cooccurring disarticulated valves of two marine bivalves: comparison of living assemblages and skeletal residues. Paleobiology, 22(4), 543-567.

Olszewski, T.D. (2004). Modeling the influence of taphonomic destruction, reworking, and burial on timeaveraging in fossil accumulations. Palaios, 19(1), $39-50$.

Parsons-Hubbard, K.M., Callender, W.R., Powell, E.N., Brett, C.E., Walker, S.E., Raymond, A.L., \& Staff, G.M. (1999). Rates of burial and disturbance of experimentally-deployed molluscs; implications for preservation potential. Palaios, 14(4), 337-351.

Parsons-Hubbard, K. (2005). Molluscan taphofacies in recent carbonate reef/lagoon systems and their application to sub-fossil samples from reef cores. Palaios, 20(2), 175-191.
Reguero, M., \& García-Cubas, A. (1994). Moluscos del complejo lagunar larga-redonda-mandinga, Vercruz, México: sitemática y ecología. Hidrobiológica, 3(12), 41-70.

Seilacher, A. (1964). Sedimentological classification and nomenclature of trace fossils. Sedimentology, 3(3), 253-256.

Taylor, P.D., \& Wilson, M.A. (2003). Palaeoecology and evolution of marine hard substrate communities. Earth Science Reviews, 62(1-2), 1-103.

Walker, S.E., Parson-Hubard, K., Powell, E.N., \& Brett, C.E. (1998). Bioerosion or bioaccumulation? Shelfslope trends for epi-and endobionts on experimentally deployed gastropod shells. Historical Biology, 13(2), 61-72.

Zuschin, M., Stachowitsch, M., \& Stanton Jr. R., (2003). Patterns and processes of shell fragmentation in modern and ancient marine environments. EarthScience Reviews, 63, 33-82. 